\title{
Electrochemistry of Caffeic Acid Aqueous Solutions with pH 2.0 to 8.5
}

\author{
Cristiano Giacomelli ${ }^{a}$, Karina Ckless ${ }^{b}$, Dayani Galato ${ }^{a, c}$, Fabio S. Miranda ${ }^{a}$ and Almir Spinelli ${ }^{* a}$ \\ ${ }^{a}$ GEPEEA - Grupo de Estudos de Processos Eletroquímicos e Eletroanalíticos, Departamento de Química - CFM, \\ Universidade Federal de Santa Catarina, 88040-900, Florianópolis - SC, Brazil
}

${ }^{b}$ Departamento de Bioquímica - CCB, Universidade Federal de Santa Catarina, 88040-900, Florianópolis - SC, Brazil

${ }^{c}$ Curso de Farmácia, Universidade do Sul de Santa Catarina, 88704-900, Tubarão - SC, Brazil

\begin{abstract}
O comportamento eletroquímico do ácido cafeico $\left(\mathrm{H}_{3} \mathrm{CAF}\right)$ em meio aquoso foi estudado na faixa de $\mathrm{pH}$ 2,0-8,5 aplicando-se as técnicas voltametria cíclica, eletrólise com potencial controlado e espectroscopia UV-vis. A eletro-oxidação envolve a transferência reversível de dois elétrons e de dois prótons em soluções de $\mathrm{pH}$ até 5,5, de acordo com o mecanismo uma etapa-dois elétrons. Em soluções de $\mathrm{pH}$ superiores a 5,5 a eletro-oxidação do $\mathrm{H}_{3} \mathrm{CAF}$ segue um mecanismo $\mathrm{EC}_{\mathrm{i}}$. O principal produto desta oxidação é a $o$-quinona correspondente ( $o$-HCAF), a qual decompõe-se rapidamente em soluções de $\mathrm{pH}$ superior a 7,4, obedecendo a uma cinética de primeira ordem. Na faixa de $\mathrm{pH} 2,0-$ 8,5 , o potencial formal $\left(\mathrm{E}^{0^{\prime}}\right)$ varia linearmente com o $\mathrm{pH}$, gerando uma reta com coeficiente angular de $-60,83 \mathrm{mV} / \mathrm{pH}$. Em paralelo, a corrente de pico anódica $\left(\mathrm{i}_{\mathrm{pa}}\right)$ diminui de modo não-linear. Os processos são controlados por difusão em toda a faixa de $\mathrm{pH}$ estudada.
\end{abstract}

The electrochemical behavior of caffeic acid $\left(\mathrm{H}_{3} \mathrm{CAF}\right)$ in aqueous solutions with $\mathrm{pH} 2.0$ to 8.5 was studied by cyclic voltammetry, controlled potential electrolysis and UV-vis spectroscopy. The electrooxidation of $\mathrm{H}_{3} \mathrm{CAF}$ involves a reversible transfer of two electrons and two protons in solutions of $\mathrm{pH}$ up to 5.5, in agreement with the one step-two electron mechanism. In solutions of $\mathrm{pH}$ higher than 5.5, the process of electro-oxidation of $\mathrm{H}_{3} \mathrm{CAF}$ follows an $\mathrm{EC}_{\mathrm{i}}$ mechanism. The main oxidation product is the corresponding $o$-quinone $(o-\mathrm{HCAF}$ ), which is decomposed quickly at $\mathrm{pH}$ higher than 7.4 obeying a first order kinetics. In the $\mathrm{pH}$ range investigated, the formal potential $\left(\mathrm{E}^{0^{\prime}}\right)$ varies linearly with $\mathrm{pH}$, generating a straight line with an angular coefficient of $-60.83 \mathrm{mV} / \mathrm{pH}$. In parallel, the anodic peak current $\left(\mathrm{i}_{\mathrm{pa}}\right)$ decreases in a nonlinear mode. The processes are controlled by diffusion over the whole $\mathrm{pH}$ range studied.

Keywords: caffeic acid, oxidation, electrochemistry, UV-vis spectroscopy

\section{Introduction}

Caffeic acid ( $\left.\mathrm{H}_{3} \mathrm{CAF}\right)$, 3-(3,4-dihydroxyphenyl)-2propenoic acid (Figure 1), is the phenylpropenoid most encountered in nature and has proven medicinal properties, especially as an antioxidant agent. ${ }^{1,2}$ Despite this, few studies have been dedicated to the oxidation mechanism of this substance. The enzymatic oxidation is the most important reaction of $\mathrm{H}_{3} \mathrm{CAF}$ in the presence of polyphenoloxidase. ${ }^{3}$ However, non-enzymatic oxidation can take place in the presence of oxygen, particularly in alkaline medium. ${ }^{4}$ Previous studies $^{3,5}$ showed that the chemical oxidation of $\mathrm{H}_{3} \mathrm{CAF}$ promoted by sodium periodate leads to the formation of the corresponding $o$-quinone (o-HCAF), 3-(cyclohex-1,5-

* e-mail: spin@qmc.ufsc.br dien-3,4-dione)-2-propenoic acid. In acidic conditions a disproportion of $o$-HCAF occurs, leading to the formation of two isomers of 2,5-(3',4'-dihydroxyphenyl) tetrahydrofuran-3,4-dicarboxylic acid. The electrooxidation of $\mathrm{H}_{3} \mathrm{CAF}$ in non-aqueous solution ${ }^{5}$ - acetonitrile - occurs in two stages, leading to the formation of the semiquinone and then to the corresponding $o$-quinone and involves the transfer of two electrons and two protons. In aqueous solution $(\mathrm{pH} 4.0)$ the electro-oxidation also involves the transfer of two electrons but there is little information about the products formed. As can be deduced from the structural formula (Figure 1), the electro-oxidation of $\mathrm{H}_{3} \mathrm{CAF}$ is $\mathrm{pH}$-dependent, and this aspect has been poorly explored in the literature. Electro-oxidation of organic compounds is carried out almost always in non-aqueous solutions due to solubility characteristics. However, this is 


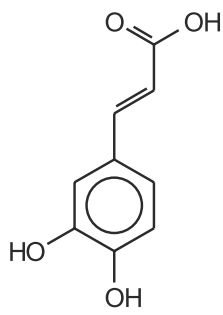

Figure 1. Chemical structure of caffeic acid $\left(\mathrm{H}_{3} \mathrm{CAF}\right)$

not the case of $\mathrm{H}_{3} \mathrm{CAF}$. The objectives of the present work are, therefore, to study the electrochemical behavior of $\mathrm{H}_{3} \mathrm{CAF}$ in solutions with $\mathrm{pH} 2.0$ to 8.5 , to characterize the products and to propose a mechanism for its electrooxidation in aqueous solution.

\section{Experimental}

\section{Chemicals}

All the reagents used in this study are of analytical grade acquired from Aldrich $\left(\mathrm{H}_{3} \mathrm{CAF}\right)$ and Merck $\left(\mathrm{H}_{3} \mathrm{PO}_{4}\right.$, $\mathrm{K}_{2} \mathrm{HPO}_{4}, \mathrm{KH}_{2} \mathrm{PO}_{4}, \mathrm{KOH}$ and citric acid). They were used without previous purification. Distilled and deionized water was used for all solution preparations.

\section{Cyclic Voltammetry}

Cyclic voltammograms were obtained in a $15-\mathrm{mL}$ threeelectrode cell, with a glassy carbon working electrode $\left(\mathrm{A}=0.0314 \mathrm{~cm}^{2}\right)$, a graphite rod counter electrode, and an aqueous saturated calomel reference electrode (SCE). All potentials in the text are quoted versus this reference electrode. The working electrode was carefully polished before each experiment with $0.05 \mu \mathrm{m}$ alumina paste and ultrasonically rinsed in deionized water. IxE curves were recorded with an EG \& G PAR model 263A potentiostat/ galvanostat with M270 software coupled to a personal computer. Buffers formed by citric acid and $\mathrm{K}_{2} \mathrm{HPO}_{4}$ or $\mathrm{KH}_{2} \mathrm{PO}_{4}$ (both $0.05 \mathrm{~mol} \mathrm{~L}^{-1}$ ) with $\mathrm{pH}$ adjusted with $\mathrm{KOH}$ or $\mathrm{H}_{3} \mathrm{PO}_{4}$ for the studied values $(2.0 ; 3.5 ; 5.5 ; 7.4 ; 8.5)$ were used as supporting electrolyte. $\mathrm{H}_{3} \mathrm{CAF}$ was added directly into the cell (final concentration $0.8 \mathrm{mmol} \mathrm{L}^{-1}$ ) after attainment of a cyclic voltammogram of the electrode immersed in the $\mathrm{H}_{3} \mathrm{CAF}$ free solution. The solutions were purged with nitrogen for $8 \mathrm{~min}$ and the experiments were done at room temperature.

\section{Controlled Potential Electrolysis}

Chronoamperometry was performed to determine the number of electrons transferred in the electro-oxidation process and to calculate, using the Cottrell equation, ${ }^{6,7}$ the diffusion coefficient of the species implicated. The experiments were carried out under the same conditions described for the cyclic voltammetry. The applied potential was $50 \mathrm{mV}$ more positive than the anodic peak potential $\left(\mathrm{E}_{\mathrm{pa}}\right)$. For the determination of the number of electrons involved in the electro-oxidation process in solutions of different $\mathrm{pH}$, the current decrease was observed until zero. The charge was obtained by integration of the resulting curve and the number of electrons was calculated. Controlled potential electrolysis was also carried out under the same conditions to identify the product of $\mathrm{H}_{3} \mathrm{CAF}$ oxidation, but graphite rods were used as working and auxiliary electrodes (the voltammetric response of $\mathrm{H}_{3} \mathrm{CAF}$ is equivalent at glassy carbon and graphite electrodes). Aliquots were extracted from the electrochemical cell and analyzed by UV-vis spectroscopy in a HITACHI U-3000 spectrophotometer before and after $10 \mathrm{~min}$ of electrolysis. The temperature of the solutions was controlled at $5{ }^{\circ} \mathrm{C}$ (Microquímica MQBTC 99-20 thermostat).

\section{Chemical oxidation of the $\mathrm{H}_{3} \mathrm{CAF}$}

The main objective of this experiment was to identify the product of $\mathrm{H}_{3} \mathrm{CAF}$ oxidation and to follow its disappearance kinetics, in view of its instability. The solutions used in this study were prepared in a way similar to the solutions used in the previous experiments, but with a constant ionic strength $\left(\mu=0.5 \mathrm{~mol} \mathrm{~L}^{-1}\right)$ controlled with $\mathrm{KCl}$. $\mathrm{H}_{3} \mathrm{CAF}$ was oxidized with $\mathrm{KMnO}_{4}$, which was added to oxidize $50 \%$ of the organic compound, admitting that the oxidation product was the corresponding $o$-quinone. ${ }^{3}$ An excess of $\mathrm{KMnO}_{4}$ was avoided to hinder the possible cleavage of the double bond of the propenoic group in acidic conditions. The identification of $o$-quinone was done by UV-vis spectroscopy and its disappearance was monitored at $400 \mathrm{~nm}$ (characteristic for $o-\mathrm{HCAF}$ absorption). The experiments were extended up to $1600 \mathrm{~s}$ after the addition of the oxidizing agent.

\section{Results and Discussion}

\section{Cyclic Voltammetry}

Figure 2 shows a typical cyclic voltammogram at a glassy carbon working electrode in a $\mathrm{pH} 2.0$ solution containing $0.8 \mathrm{mmol} \mathrm{L}^{-1} \mathrm{H}_{3} \mathrm{CAF}$, for a scan rate $(v)$ of 100 $\mathrm{mV} \mathrm{s}^{-1}$. The cyclic voltammogram is characteristic of an electrochemically reversible reaction showing only one anodic peak $\left(\mathrm{E}_{\mathrm{pa}}=507 \mathrm{mV}\right)$ and one cathodic peak $\left(\mathrm{E}_{\mathrm{pc}}=\right.$ 


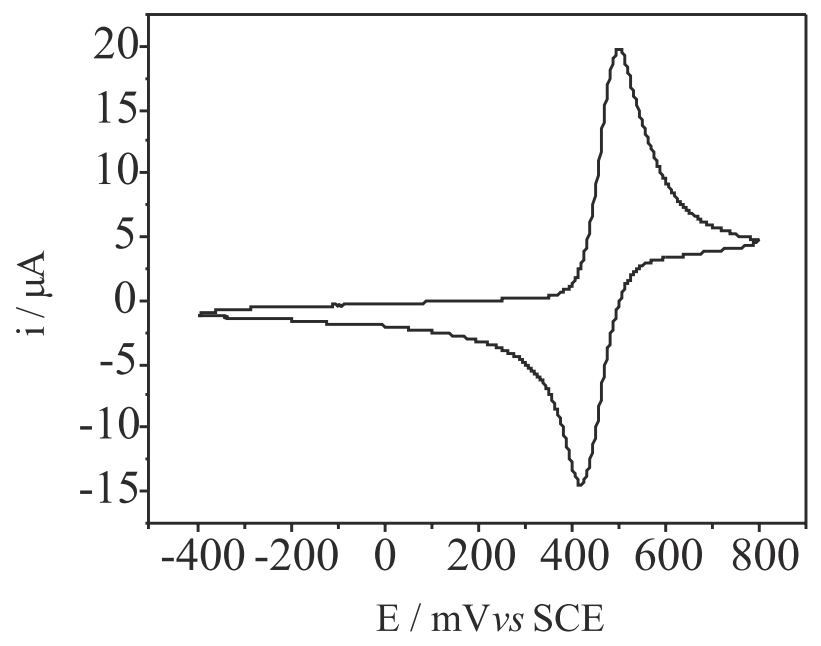

Figure 2. Cyclic voltammogram for $0.8 \mathrm{mmol} \mathrm{L}^{-1} \mathrm{H}_{3} \mathrm{CAF}$ in $\mathrm{pH} 2.0$ solution at a glassy carbon electrode, $v=100 \mathrm{mV} \mathrm{s}^{-1}$

$415 \mathrm{mV}$ ). The voltammogram profile does not change significantly even after 20 cycles. The ratio $\mathrm{i}_{\mathrm{pc}} \cdot \mathrm{i}_{\mathrm{pa}}{ }^{-1}=0.954$ confirms the reversibility of the system under these conditions. The formal potential $\left(\mathrm{E}^{01}\right)$ of the electrochemically reversible couple that quickly changes electrons with the working electrode is centered between $\mathrm{E}_{\mathrm{pa}}$ and $\mathrm{E}_{\mathrm{pc}}{ }^{8}{ }^{8}$ For the system in study $\left(\mathrm{E}_{\mathrm{pa}}+\mathrm{E}_{\mathrm{pc}}\right) / 2=461 \mathrm{mV}$. It is interesting to note that this value is very close to the standard potential $\left(\mathrm{E}^{0}\right)$ and to the formal potential $\left(\mathrm{E}^{01}\right)$ in different acidic conditions of the redox couple quinonehydroquinone $\left(\mathrm{E}^{0}=455 \mathrm{mV}\right.$ and $\mathrm{E}^{0}=452 \mathrm{mV}$ in $1.0 \mathrm{~mol} \mathrm{~L}^{-1}$ $\mathrm{H}_{2} \mathrm{SO}_{4}, \mathrm{HClO}_{4}$ and $\mathrm{HCl}$ ). ${ }^{9}$ This result suggests that the couple implicated in the electro-oxidation of caffeic acid in $\mathrm{pH}$ 2.0 solutions is $\mathrm{H}_{3} \mathrm{CAF}-\mathrm{o}-\mathrm{HCAF}$ involving the transfer of two electrons and two protons. However the value of $\mathrm{E}_{\mathrm{pa}}-$ $\mathrm{E}_{\mathrm{pa} / 2}=51 \mathrm{mV}$ is not expected for this type of electron transfer. This value should be close to $30 \mathrm{mV}$ for a reversible two-electron transfer. The difference between the obtained and expected value indicates, however, that the charge transfer is not sufficiently fast under the studied conditions and that reaction is not completely reversible, as demonstrated below.

\section{Influence of $\mathrm{pH}$}

The influence of $\mathrm{pH}$ on the cyclic voltammograms at a glassy carbon electrode in $0.8 \mathrm{mmol} \mathrm{L}^{-1} \mathrm{H}_{3} \mathrm{CAF}$ solutions, $v=100 \mathrm{mV} \mathrm{s}^{-1}$, is shown in Figure 3. It is observed that the profile of the IxE curves is the same in the $\mathrm{pH}$ range studied, indicating that the electro-oxidation of $\mathrm{H}_{3} \mathrm{CAF}$ follows the same reaction mechanism. However, with the increase of $\mathrm{pH}$, the anodic and cathodic peak potentials are shifted toward less positive values. The shift of $\mathrm{E}_{\mathrm{pa}}$ to less positive values indicates an increase in the nucleophilicity of the organic compound, ${ }^{10}$ and that its antioxidant activity is thermodynamically favored with the $\mathrm{pH}$ increase. Some authors have described the same dependence for oxidation of $\mathrm{H}_{3} \mathrm{CAF}$, gallic acid and derivatives. ${ }^{11,12}$ On the other hand, in 50/50 (v/v) water-methanol solvent, the anodic peak potential shifts to more positive values with an increase in $\mathrm{pH} .{ }^{5}$ In addition we observed that the separation between the peak potentials is also $\mathrm{pH}$-dependent. The large separation between the anodic and cathodic peak potentials in the $\mathrm{pH} 8.5$ cyclic voltammogram is a manifestation of sluggish heterogeneous electron transfer kinetics. ${ }^{8}$ Figure 4 shows the linear decrease of $\mathrm{E}^{01}$ as a function of $\mathrm{pH}$ with $-60.83 \mathrm{mV} \mathrm{pH}^{-1}$ slope (correlation coefficient $r=-0.9907$ ). This value is close to that expected for Nernstian systems with electron transfer followed by deprotonation. Figures 3 and 4 show that $i_{p a}$ decreases in a

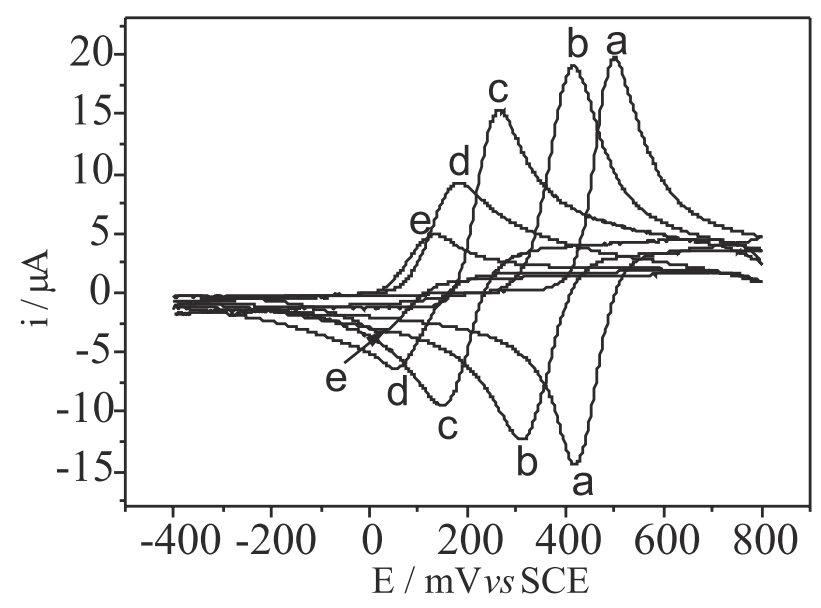

Figure 3. Cyclic voltammograms for $0.8 \mathrm{mmol} \mathrm{L}^{-1} \mathrm{H}_{3} \mathrm{CAF}$ in $\mathrm{pH}$ (a) 2.0 ; (b) 3.5 ; (c) 5.5 ; (d) 7.4 and (e) 8.5 solutions at a glassy carbon electrode, $v=100 \mathrm{mV} \mathrm{s}^{-1}$

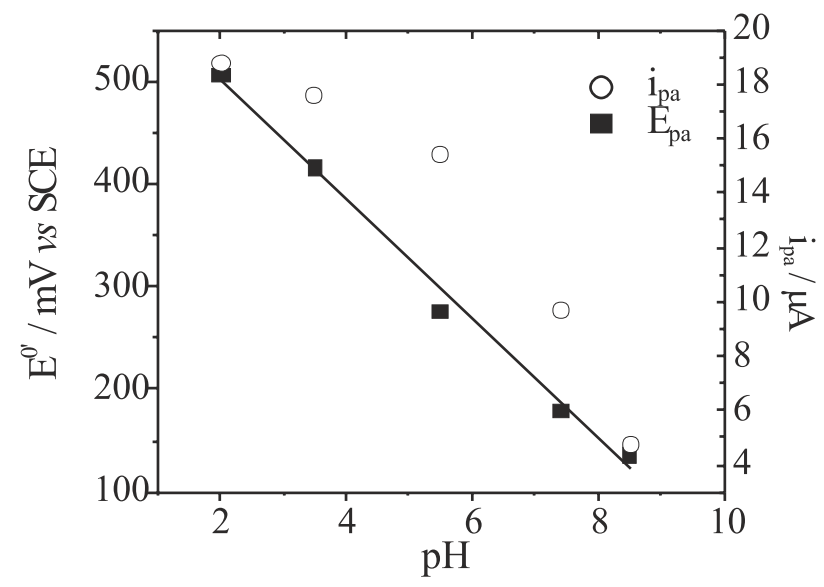

Figure 4. Formal potential and anodic peak current as a function of $\mathrm{pH}$ for $0.8 \mathrm{mmol} \mathrm{L}^{-1} \mathrm{H}_{3} \mathrm{CAF}$ 
nonlinear way with increasing $\mathrm{pH}$. The decrease of $\mathrm{i}_{\mathrm{pa}}$ as a function of $\mathrm{pH}$ can be associated to the concentration and to the diffusion coefficient of the electro-active species that effectively are being oxidized, as demonstrated below. Figure 5 shows the composition of the $\mathrm{H}_{3} \mathrm{CAF}$ solutions (alpha values) as a function of $\mathrm{pH}$. Under the conditions of air experiments we have: $\mathrm{pH} 2.0: 99 \%$ of $\mathrm{H}_{3} \mathrm{CAF}$ and 1\% of $\mathrm{H}_{2} \mathrm{CAF} ; \mathrm{pH} 3.5: 88 \%$ of $\mathrm{H}_{3} \mathrm{CAF}$ and $12 \%$ of $\mathrm{H}_{2} \mathrm{CAF}^{-} ; \mathrm{pH}$ 5.5: $8 \%$ of $\mathrm{H}_{3} \mathrm{CAF}$ and $92 \%$ of $\mathrm{H}_{2} \mathrm{CAF} ; \mathrm{pH} 7.4: 94 \%$ of $\mathrm{H}_{2} \mathrm{CAF}^{-}$and $6 \%$ of $\mathrm{HCAF}^{2-} ; \mathrm{pH}^{2} .5: 58 \%$ of $\mathrm{H}_{2} \mathrm{CAF}^{-}$and $42 \%$ of $\mathrm{HCAF}^{2-}$. Thus, at this time, if one accepts that the oxidation processes of these species are represented by the reactions shown in Figure 6, the dependence of $i_{p a}$ with $\mathrm{pH}$ can be explained as follows: at $\mathrm{pH} 2.0$ and $3.5, \mathrm{i}_{\mathrm{pa}}$ practically does not change, therefore the species that is being oxidized is $\mathrm{H}_{3} \mathrm{CAF}$, its concentration at the two $\mathrm{pH}$ being practically the same. The current for the electrochemical reaction (at a mass transport rate) of an electro-active material with a diffusion coefficient, $\mathrm{D}$, is described by the Cottrel equation: ${ }^{6,7}$

$$
\mathrm{i}=\mathrm{nFAD}^{1 / 2} \mathrm{C}_{\mathrm{b}} / \pi^{1 / 2} \mathrm{t}^{1 / 2}
$$

where $\mathrm{D}$ is the diffusion coefficient $\left(\mathrm{cm}^{2} \mathrm{~s}^{-1}\right)$ and $\mathrm{C}_{\mathrm{b}}$ is the bulk concentration of substrate. $\mathrm{n}, \mathrm{F}, \mathrm{A}$ and $\mathrm{t}$ have their usual significance. Under diffusion (mass transport) control, a plot of $i$ versus $\mathrm{t}^{-1 / 2}$ will be linear and, from the slope, the value of $\mathrm{D}$ can be obtained. Chronoamperometry was performed and a diffusion coefficient $\mathrm{D}=2.3 \times 10^{-5}$ $\mathrm{cm}^{2} \mathrm{~s}^{-1}$ (pH 2.0) was obtained. When the $\mathrm{pH}$ progressively changes from 3.5 to 8.5 , it is observed that $\mathrm{i}_{\mathrm{pa}}$ becomes more $\mathrm{pH}$ dependent. As the number of electrons involved in the process is always the same, the decrease of $i_{p a}$ is

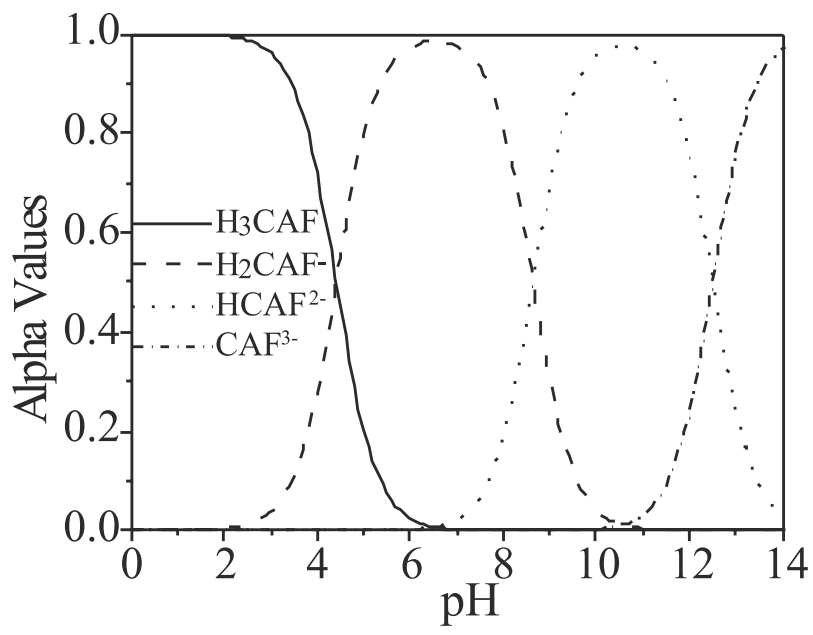

Figure 5. Composition of $\mathrm{H}_{3} \mathrm{CAF}$ solutions as a function of $\mathrm{pH}\left(\mathrm{pK}_{\mathrm{a} 1}\right.$ $=4.41, \mathrm{pK}_{\mathrm{a} 2}=8.64, \mathrm{pK}_{\mathrm{a} 3}=12.5^{13}$ certainly associated with a reduction of the concentration and/or of the diffusion coefficient of the involved species. As at $\mathrm{pH} 3.5$ there are already more than one species in solution, it is impossible to associate the diffusion coefficient calculated from the Cottrell equation with the diffusion coefficient of one particular species. Under these conditions, the obtained value would be a compilation of the diffusion coefficients of all species present, as considered by Schifino et al. ${ }^{14} \mathrm{We}$ also observed that the diffusion coefficient gradually diminishes from $2.3 \times 10^{-5}$ $\mathrm{cm}^{2} \mathrm{~s}^{-1}$ to $0.49 \times 10^{-5} \mathrm{~cm}^{2} \mathrm{~s}^{-1}$ when the $\mathrm{pH}$ is increased from 2.0 to 8.5 . This indicates, in a first approach, that the species would have gradually smaller diffusion coefficients as they were being deprotonated.

It is important to note that the dependence of $\mathrm{E}_{\mathrm{pa}}$ with $\mathrm{pH}$ is attenuated when the $\mathrm{pH}$ changes from 7.4 to 8.5 (Figure 3). This behavior can be explained by the increase of the concentration of $\mathrm{HCAF}^{2-}$ in solution. In the oxidation of $\mathrm{HCAF}^{2-}$, only one proton is involved (Figure 6 , reaction 3 ), while in the oxidation of the other species two protons are involved.

(1)<smiles>O=C(O)/C=C/C1=CC(=O)C(=O)C=C1</smiles>

(2)<smiles>O=C([O-])/C=C/C1=CC(=O)C(=O)C=C1</smiles>

(3)<smiles>O=C([O-])/C=C/C1=CC(=O)C(=O)C=C1</smiles>

(4)

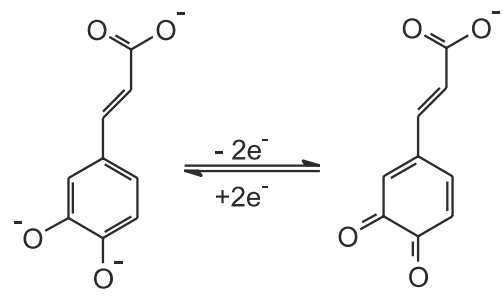

Figure 6. Oxidation reactions for $\mathrm{H}_{3} \mathrm{CAF}$ (reaction 1), $\mathrm{H}_{2} \mathrm{CAF}^{-}$(reaction 2), $\mathrm{HCAF}^{2-}$ (reaction 3) and $\mathrm{CAF}^{3-}$ (reaction 4) 
In solutions of $\mathrm{pH}$ higher than 8.5 the reduction peak was not observed (data not shown), which indicates that the product of oxidation of $\mathrm{H}_{3} \mathrm{CAF}$ became unstable and an irreversible homogeneous chemical reaction occurs. For this reason we limited our studies to the $\mathrm{pH}$ range 2.0-8.5.

\section{Influence of the scan rate}

The influence of the scan rate on the anodic peak potential $\left(\mathrm{E}_{\mathrm{pa}}\right)$ is shown in Figure 7 for the $\mathrm{pH}$ range studied. It is verified that the system under study presents a reversible behavior for scan rates up to $100 \mathrm{mV} \mathrm{s}^{-1}$ and an increasing irreversibility for faster scan rates. In parallel, the anodic peak current $\left(\mathrm{i}_{\mathrm{pa}}\right)$ increases linearly with $v^{1 / 2}$ (Figure 8), indicating that the process is diffusion limited over the whole $\mathrm{pH}$ range studied.

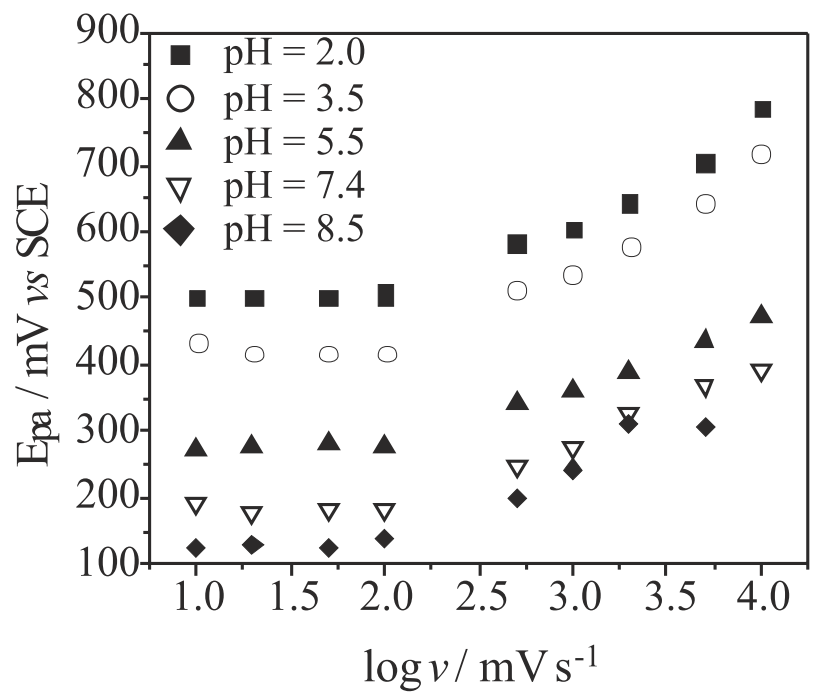

Figure 7. Influence of the scan rate on the anodic peak potential $\left(\mathrm{E}_{\mathrm{pa}}\right)$ for $0.8 \mathrm{mmol} \mathrm{L} \mathrm{m}_{3} \mathrm{CAF}$ solutions of different $\mathrm{pH}$

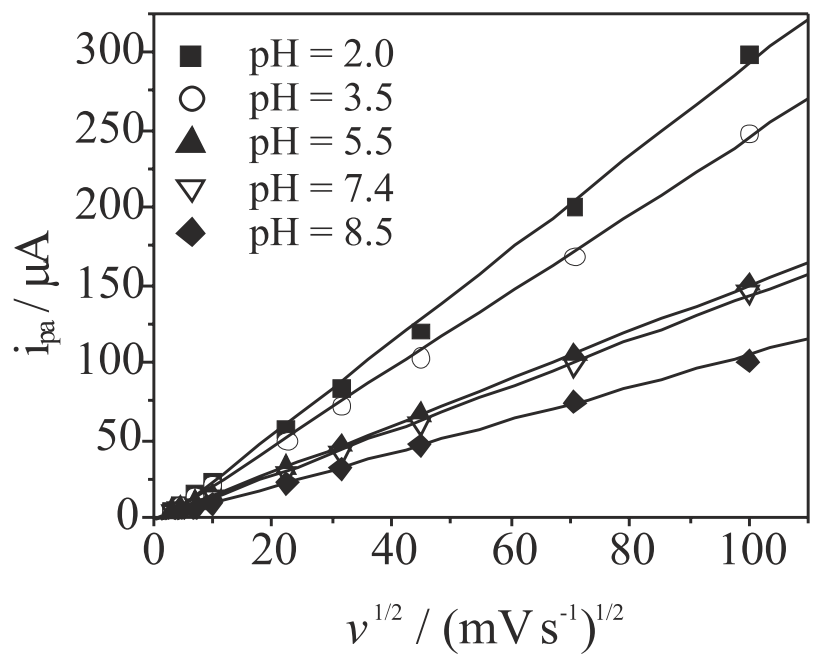

Figure 8. Influence of the scan rate on anodic peak current $\left(\mathrm{i}_{\mathrm{pa}}\right)$ for $0.8 \mathrm{mmol} \mathrm{L}^{-1} \mathrm{H}_{3} \mathrm{CAF}$ solutions of different $\mathrm{pH}$
Influence of slow scan rates in alkaline solutions

Figure 9 shows cyclic voltammograms at a glassy carbon working electrode in $\mathrm{pH} 2.0$ and 8.5 solutions containing $0.8 \mathrm{mmol} \mathrm{L}^{-1} \mathrm{H}_{3} \mathrm{CAF}, v=5 \mathrm{mV} \mathrm{s}^{-1}$. It is observed that at $\mathrm{pH} 2.0$ the electro-oxidation of $\mathrm{H}_{3} \mathrm{CAF}$ is reversible $\left(\mathrm{i}_{\mathrm{pc}} \cdot \mathrm{i}_{\mathrm{pa}}{ }^{-1} \sim 1\right)$. This ratio decreased as the $\mathrm{pH}$ increased and, at $\mathrm{pH} 8.5$, the reduction peak was not observed, denoting that the product of $\mathrm{H}_{3} \mathrm{CAF}$ oxidation (that is the corresponding $o$-quinone (o-HCAF)) became unstable, resulting, therefore, in only partial reduction. We observed that $o-\mathrm{HCAF}$ is more stable in solutions of $\mathrm{pH} \leq 5.5$. For solutions of $\mathrm{pH} \geq 7.4$ the stability of $o$-HCAF diminished significantly, implying an expressive increase of its disappearance rate. The instability of $o$-HCAF at $\mathrm{pH} \geq 7.4$ suggests the involvement of $\mathrm{HCAF}^{2-}$ ions, which have a high nucleophilicity. The influence of the nucleophiles on the stability of $o$-quinones was also suggested by Nematollahi et al. ${ }^{15}$ At $\mathrm{pH} \leq 5$ (in the presence of $\mathrm{H}_{3} \mathrm{CAF}$ and $\mathrm{H}_{2} \mathrm{CAF}^{-}$ions) $o$-HCAF is stable, while at higher $\mathrm{pH}$ (in the presence of only $\left.\mathrm{HCAF}^{2-}\right), o-\mathrm{HCAF}$ is less stable.

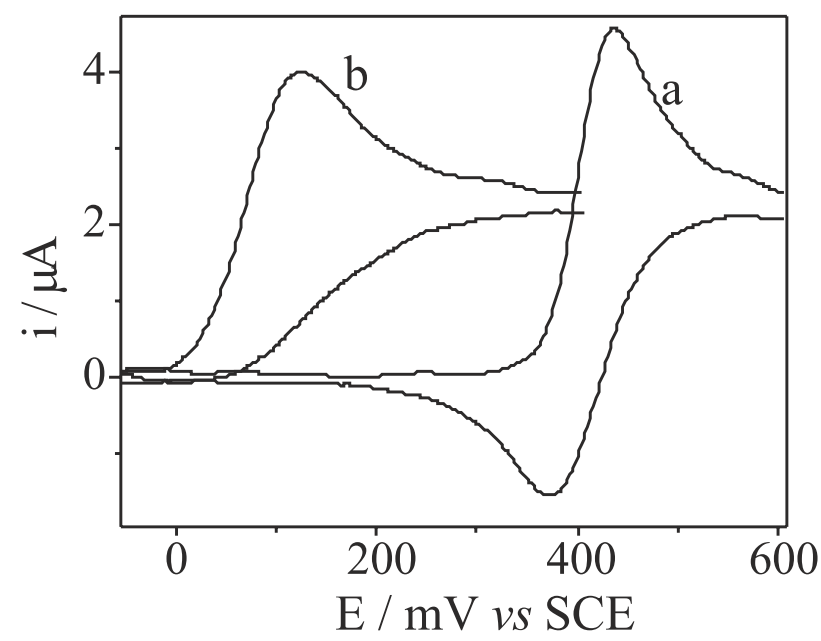

Figure 9. Cyclic voltammograms for $0.8 \mathrm{mmol} \mathrm{L}^{-1} \mathrm{H}_{3} \mathrm{CAF}$ in $\mathrm{pH}$ (a) 2.0 and (b) 8.5 solutions at a glassy carbon electrode, $v=5 \mathrm{mV} \mathrm{s}^{-1}$

\section{Controlled potential electrolysis}

Electrolyses with controlled potentials were carried out to confirm the number of electrons involved and to identify $o$-HCAF as the product of oxidation of $\mathrm{H}_{3} \mathrm{CAF}$. The number of electrons involved in the oxidation of $\mathrm{H}_{3} \mathrm{CAF}$ in the $\mathrm{pH}$ range studied was found to be two (Table 1 ). The identification of $o$-HCAF was carried out by UV-vis spectroscopy. Electrolysis was performed with the cell temperature kept at $5{ }^{\circ} \mathrm{C}$, in view of the instability of $o$ $\mathrm{HCAF}$ at higher temperatures. 
Table 1. Parameters obtained from chronoamperometric experiments

\begin{tabular}{ccc}
\hline $\mathrm{pH}$ & Charge $/(\mathrm{mC})$ & Number of electrons \\
\hline 2.0 & 2355 & 1.912 \\
3.5 & 2424 & 1.968 \\
5.5 & 2323 & 1.886 \\
7.4 & 2192 & 1.780 \\
8.5 & 2619 & 2.126 \\
\hline
\end{tabular}

Figure 10 shows the UV-vis spectra for $0.8 \mathrm{mmol} \mathrm{L}^{-1}$ $\mathrm{H}_{3} \mathrm{CAF}$ in $\mathrm{pH} 2.0$ solution for $\mathrm{t}=0$ and after $10 \mathrm{~min}$ of electrolysis. No absorption band was observed before electrolysis $(\mathrm{t}=0)$. A large band around $400 \mathrm{~nm}$ was observed after electrolysis which was attributed to $o$-HCAF, since this substance presents a characteristic absorption band at this wavelength. ${ }^{3}$ This absorption band was also observed in aliquots of solutions with $\mathrm{pH}$ higher than 2.0, presenting a small wavelength shift to lower energy (406 $\mathrm{nm}$ at $\mathrm{pH}$ 7.4).

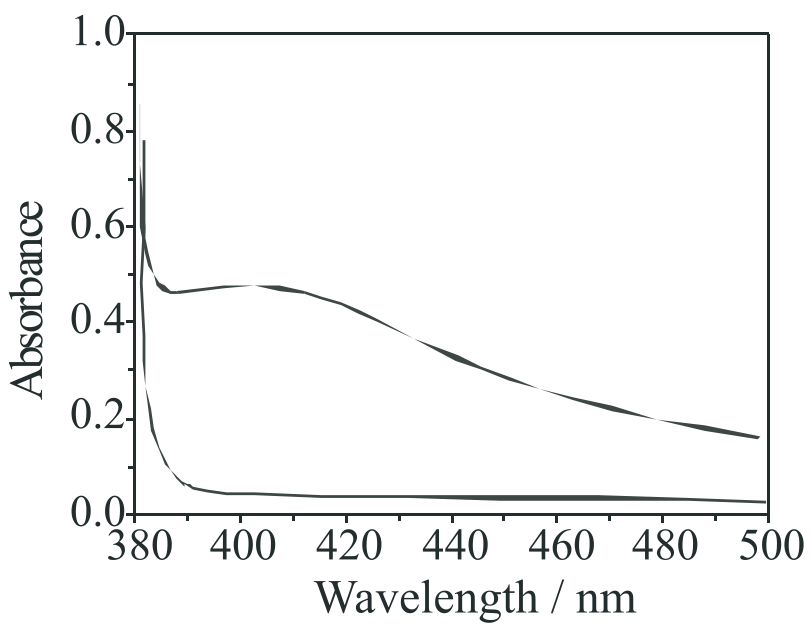

Figure 10. UV-vis spectra for $0.8 \mathrm{mmol} \mathrm{L}^{-1} \mathrm{H}_{3} \mathrm{CAF}$ in $\mathrm{pH} 2.0$ solution after (a) zero and (b) 10 min of electrolysis, temperature $=5{ }^{\circ} \mathrm{C}$

These studies therefore confirmed that, in the process of $\mathrm{H}_{3} \mathrm{CAF}$ electro-oxidation, two electrons are involved and that the main product formed is the corresponding $o$ quinone.

\section{Kinetic study of the disappearance of o-HCAF}

During these studies we observed that the $o$-quinone resulting from the oxidation of $\mathrm{H}_{3} \mathrm{CAF}$ was fairly unstable at room temperature, which is a characteristic behavior of many quinones, mainly in the presence of nucleophiles. Therefore, this behavior was studied as a function of $\mathrm{pH}$.
Chemical oxidation of $\mathrm{H}_{3} \mathrm{CAF}$ with $\mathrm{KMnO}_{4}$ was promoted and an absorption band around $400 \mathrm{~nm}$, attributed to $o$ HCAF, repeats. ${ }^{3}$ The decrease of the absorption band at $400 \mathrm{~nm}$ as a function of time allows one to study the kinetics of $o$-HCAF disappearance, ${ }^{16}$ as shown in Figure 11. The kinetics of disappearance of $o-\mathrm{HCAF}$ involves a first-order reaction, as recognized by other authors. ${ }^{3}$ In $\mathrm{pH}$ $\leq 5.5$ solutions $o$-HCAF is sufficiently stable. When the $\mathrm{pH}$ is higher than 5.5 the $o$-HCAF instability increases, as it can be verified observing an enhancement of kinetics of its disappearance. These results are in accordance with those observed in the electrochemical experiments, where an increasing irreversibility at $\mathrm{pH}$ higher than 5.5 was shown. As mentioned previously, this behavior suggests that $\mathrm{HCAF}^{2-}$ ions are related to the instability of $o$-HCAF. However this approach is beyond the objective of this work.

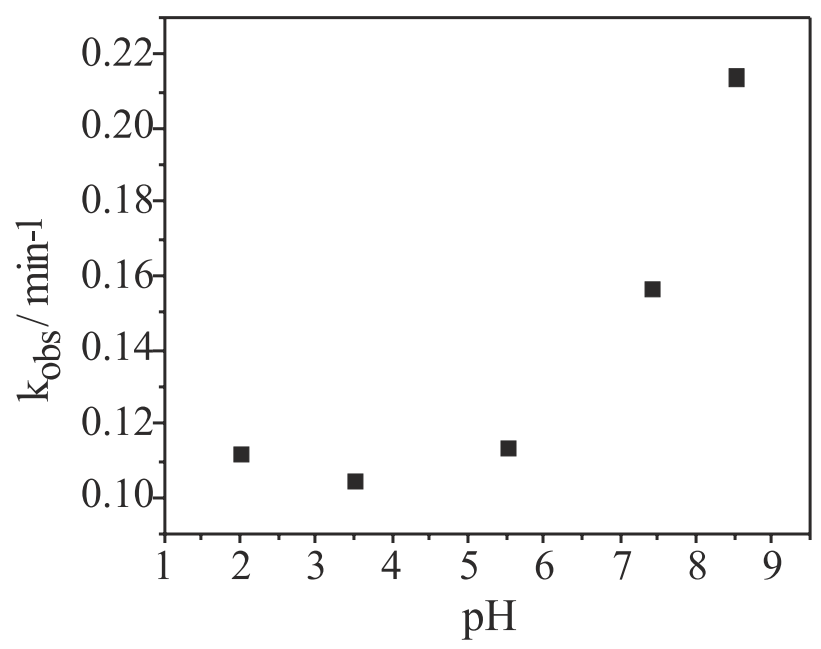

Figure 11. Effect of $\mathrm{pH}$ on the experimental rate constant (k) for $o$ HCAF disappearance. Ionic strength $=0.5 \mathrm{~mol} \mathrm{~L}^{-1}$; Temperature $=$ $25{ }^{\circ} \mathrm{C}$

\section{Conclusions}

The results obtained in these studies show that $\mathrm{H}_{3} \mathrm{CAF}$ is reversibly oxidized in solutions of $\mathrm{pH}$ up to 5.5. The electro-oxidation follows a mechanism involving only one step with the transfer of two electrons and two protons. The $\mathrm{H}_{3} \mathrm{CAF}$ oxidation product was identified as being the corresponding $o$-quinone. For $\mathrm{pH}$ values higher than 5.5 $o$-HCAF becomes unstable, with a chemically homogeneous irreversible reaction with a first order kinetics occurring. Under these conditions the mechanism is of the $\mathrm{EC}_{\mathrm{i}}$ type. The proposed electro-oxidation mechanisms shown in Figure 12 take these comments into consideration. Reaction 1 can be accepted for $\mathrm{H}_{3} \mathrm{CAF}$ and $\mathrm{H}_{2} \mathrm{CAF}^{-}$in solutions of $\mathrm{pH}$ up to 5.5. A fast reaction follows 


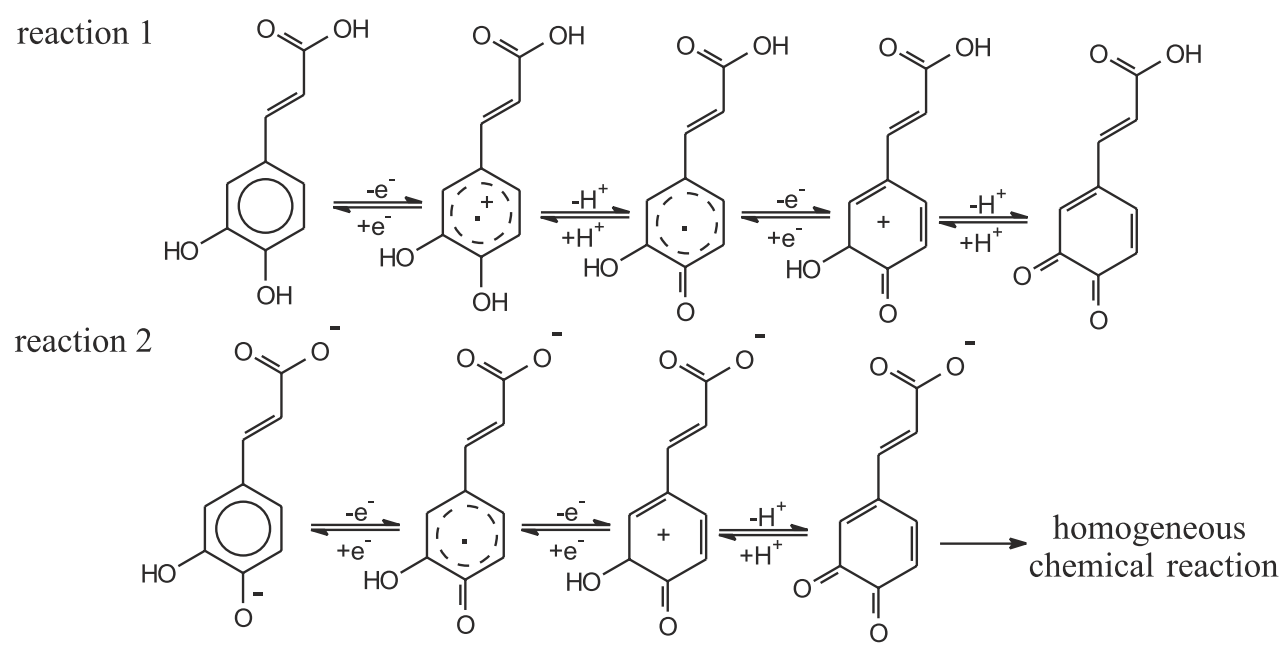

Figure 12. Proposed mechanisms for the electro-oxidation of $\mathrm{H}_{3} \mathrm{CAF}$

a one step-two electron type mechanism. The intermediates cannot be identified by electrochemical methods under our experimental conditions, but the results obtained indicate that the reaction occurs with charge transfer, followed by deprotonation, supporting the proposed mechanisms. Although the $\mathrm{H}_{2} \mathrm{CAF}^{-}$species are present even at $\mathrm{pH} 8.5$, from $\mathrm{pH} 7.4$ (and even at slightly acid $\mathrm{pH}$ ) there are also $\mathrm{HCAF}^{2-}$ groups present. In the oxidation of $\mathrm{HCAF}^{2-}$ two electrons are also involved but the reaction is less dependent on $\mathrm{pH}$ (Figure 12, reaction 2). We believe that $\mathrm{HCAF}^{2-}$ is also responsible for the instability of the $o$ quinone formed and is the basis of a slow irreversible chemical reaction with first order kinetics.

\section{Acknowledgments}

The authors are grateful to CNPq for financial support.

\section{References}

1. Nardini, M.; Pisu, P.; Gentili, V.; Natella, F.; Di Felice, M.; Piccolella, E.; Scaccini, C.; Free Radical Biol. Med. 1998, 25, 1098.

2. Galato, D.; Ckless, K.; Susin M. F.; Giacomelli, C.; Ribeiro-doValle, R. M.; Spinelli, A.; Redox Report 2001, 6, 243.

3. Fulcrand, H.; Cheminat, A.; Brouillard, R.; Cheynier V.; Phytochemistry 1994, 35, 499.

4. Cilliers, J. J. L.; Singleton, V. L.; J. Agric. Food Chem. 1989, 37,890 .

5. Hapiot, P.; Neudeck, A.; Pinson, J.; Fulcrand, H.; Neta, P.; Rolando, C.; J. Electroanal. Chem. 1996, 405, 169.
6. Bard, A. J.; Faulkner, L. R.; Electrochemical Methods, Fundamentals and Applications, John Wiley \& Sons Inc: New York, 1980, p 142.

7. Brett, C. M. A.; Brett, A. M. O.; Electrochemistry: Principles, Methods, and Applications, Oxford University Press: New York, 1993, p 87.

8. Sawyer, D. T.; Heineman, W. R.; Beebe, J. M.; Chemistry Experiments for Instrumental Methods, John Wiley \& Sons: New York, 1984, p 79.

9. Skoog, D.A.; West, D. M.; Holler, F. J.; Fundamentals of Analytical Chemistry, $6^{\text {th }}$ ed., Saunders College Publishing: New York, 1992, appendix 6.

10. Sawyer, D. T.; Sobkowiak, A.; Roberts Jr., J. L.; Electrochemistry for Chemists, $2^{\text {nd }}$ ed., John Wiley \& Sons Inc: New York, 1995, p 442.

11. Zare, H.R.; Golabi, S.M.; J. Solid State Electrochem. 2000, 4, 87.

12. Gunckel, S.; Santander, P.; Cordano, G.; Ferreira, J.; Munoz, S.; Nunez-Vergara, L. J.; Squella, J. A.; Chemico-Biological Interactions 1998, 114, 45.

13. Martell, A. E.; Smith, R. M.; Critical Stability Constants, Plenum Press: New York, 1976, vol. 4.

14. Schifino, J.; Basso, N. R. de S.; Olegário, R. M.; Quím. Nova 1991, 14, 254.

15. Golabi, S. M.; Nematollahi, D.; J. Electroanal. Chem. 1997, 420, 127.

16. Atkins, P. W.; Physical Chemistry, $5^{\text {th }}$ ed., Oxford University Press: New York, 1994, p. 864.

Received: April 6, 2001

Published on the web: April 18, 2002 